\title{
Undergraduate Nonprofit Education: Between Institutionalization and Recruitment
}

\author{
Carol Brunt \\ University of Wisconsin-Whitewater \\ Norman A. Dolch \\ University of North Texas \\ Tyrone M. Freeman \\ Indiana University-Purdue University at Indianapolis \\ Roseanne Mirabella \\ Seton Hall University \\ Peter C. Weber \\ Auburn University \\ Michelle Wooddell \\ Grand Valley State University
}

The development of nonprofit and philanthropic studies (NPS) has followed the historical trends of the nonprofit sector (Weber \& Witkowski, 2016). The increasing professionalization of the nonprofit sector in the 1980s expanded the need for specific training in nonprofit management, administration, and leadership of nonprofit professionals (Mirabella \& Renz, 2001). Over the past three decades, the development of NPS has been driven by professionalization (focus on practitioners) and academicization (focus on a scholarly/academic field). The interplay, although not without tension, has facilitated the development of graduate education, as the research and professionalizing

Carol Brunt is an assistant professor, Department of Management, University of Wisconsin-Whitewater. Norman A. Dolch is an adjunct professor, Department of Public Administration, University of North Texas. Tyrone M. Freeman is an assistant professor of Philanthropic Studies, Indiana University Lilly Family School of Philanthropy at IUPUI. Roseanne Mirabella is a professor, Department of Political Science and Public Affairs, and executive director, Center for Community Research and Engagement, Seton Hall University. Peter C. Weber is an assistant professor of philanthropy and nonprofit studies, Department of Consumer and Design Sciences, Auburn University. Michelle Wooddell is an assistant professor, Department of Public, Nonprofit, and Health Administration, Grand Valley State University. Please send author correspondence to pcw0015@auburn.edu 
impetus naturally focus on graduate students because practitioners in the field tend to already possess bachelor's degrees.

Not surprisingly, much of the research on NPS and the institutionalization of the field has focused on graduate schools and programs. Pioneering research on nonprofit education by scholars such as Roseanne Mirabella, Norman Dolch, and Dennis Young, to name a few, has analyzed a variety of factors such as increases over time in the number and focus of course offerings (Mirabella, 2007), institutional location and student perception (Mirabella \& Renz, 2001; Mirabella \& Wish, 2000), and effect (Fletcher, 2005; Mirabella \& Wish, 1999). These studies predominantly focus on the graduate level. By contrast, research on undergraduate education has adopted broader conceptual frameworks such as civic engagement rather than the narrower focus on NPS. Studies have consequently focused on service learning and student philanthropy, with particular attention to curriculum design and practices (Benenson \& Moldow, 2017; Hatcher \& Studer, 2015; Olberding, 2012), learning outcomes (Campbell, 2014; T. Mitchell, 2015), and long-term effects on civic identity and community (McDonald, Miller, \& McDougle, 2017; Olberding \& Hacker, 2016).

The Nonprofit Management Education database compiled by Roseanne Mirabella substantiates the graduate orientation of the field. As of 2018, 343 schools/universities offer courses in NPS. Of these schools, 251 offer courses at the graduate level and 144 at the undergraduate level. However, these data, impressive if seen as a trend over the past few decades, use number of courses as an indicator of the growth of the NPS field. Shifting the attention from number of courses to number of programs offering a certificate, major, or minor reveals a much smaller number at the undergraduate level compared to the graduate level. Besides the study analyzing various delivery models for NPS by Dolch, Ernst, McClusky, Mirabella, and Sadow (2007), no comprehensive analysis exists of undergraduate programs in the field. However, initial research by Weber and Brunt (2019) shows that in contrast to the 379 schools offering a master's degree or graduate certificate in NPS, only 104 offer a bachelor's, minor, or certificate at the undergraduate level, and among these only 26 offer a stand-alone bachelor's degree in NPS.

This study aims to start a discussion on the challenges in the development of undergraduate educational programs in NPS. Undergraduate NPS programs (certificates, minors, and majors) have been developing at a slower pace than their graduate counterparts. Accordingly, we focus on the development of these programs, analyze their challenge of recruitment, and review the state of undergraduate NPS overall. Against this broader context, we selected four case studies for a more in-depth analysis of the challenges NPS programs face and the strategies these programs adopt to overcome these challenges. The selected institutions substantially vary in (1) location (rural vs. metropolitan), (2) student demographics, (3) institutional support, and (4) sources of funding. The analysis suggests that common concerns include (1) development of programs broad enough to allow students to pursue multiple career and educational paths after graduation, which forces a curriculum development that differs from the path laid out at the graduate level, and (2) prospective students', parents', and high school counselors' misconceptions and lack of knowledge about nonprofit careers. 


\section{Literature Review}

NPS at the undergraduate level has evolved over time, with an increasing number of courses and concentrations being offered in a variety of settings. Although programs in NPS at the undergraduate level have experienced growth, there is limited research on these programs, as they are typically clustered with graduate level NPS. Although the scholarship on these educational programs has exploded, including the development of a journal specifically focused on NPS programs-the Journal of Nonprofit Education and Leadership - the focus on undergraduate NPS programs continues to be a somewhat limited.

The trajectory of undergraduate programs in NPS over time has been tracked by a database created by Seton Hall University (http://academic.shu.edu/npo/). This database, updated periodically, contains the types of NPS programs offered by universities, along with the courses offered within these programs. Overall, this database addresses the nature and types of undergraduate programs in the United States (Dolch et al., 2007; Mirabella, Hoffman, Teo, \& McDonald, 2019).

In 1998, Dolch, Kidwell, Sadow, and Smith developed four models to explain how undergraduate nonprofit education is taught. These models were originally developed to describe undergraduate American Humanics programs; however, Dolch et al. (2007) later utilized these models to examine programs beyond those involved with American Humanics. The four models identified by Dolch et al. (2007) include certificate programs, academic minors, academic majors, and programs combining the three (p. 32S). The identification of these four models helps researchers to study undergraduate NPS programs, by making categorization and comparisons simpler.

A large portion of the research on undergraduate NPS programs has focused on case studies examining specific universities that offer these types of programs and describing their histories, structures, and courses. By looking at specific examples, researchers have been able to illustrate the state of undergraduate NPS programs and demonstrate what each type of program entails, therefore showcasing the differences between them. Additionally, through these case studies, researchers have been able to demonstrate the trajectory of undergraduate NPS programs, therefore illustrating how these programs developed into today's programs (Ashcraft, 2000; Dolch, 2018; Rinella, 2016).

The conversion of American Humanics to the Nonprofit Leadership Alliance is one of the major shifts the the undergraduate NPS field has undergone throughout its evolution. From its beginning in 1948, American Humanics was the sole organization devoted to the development and support of undergraduate programs in NPS, with a primary focus on youth and human service agencies (Ashcraft, 2001, p. 43). The organization's goal was to prepare upcoming leaders in the nonprofit field through an alliance between three stakeholder groups: national nonprofit partners, collaborating professional organizations, and higher education institutions (Ashcraft, 2001, p. 45). The resulting certificate program offered at the partnering higher education institutions required students to become knowledgeable in nonprofit management, finance, and fundraising and included a strong focus on experiential learning through internships and workshops (Stroup, 2006, pp. 42-43). 
In 2002, American Humanics began to experience changes resulting from its desire to become more inclusive of the entire nonprofit sector as opposed to its initial focus on youth and human service agencies. To mark this change, American Humanics changed its name to the Nonprofit Leadership Alliance and began to seek national partnerships in the nonprofit sector that went beyond youth and human service agencies (Altman, Carpenter, Dietrick, Strom, \& VanHorn, 2012, p. 126). Nevertheless, the organization's goal of educating the next generation of nonprofit leaders remained the same, including its strong emphasis on experiential learning and service learning (Gillman \& Ceglian, 2012).

The effect of the Nonprofit Leadership Alliance on undergraduate NPS education is undeniable, not surprising given its tremendous influence on students, graduates, and curricular development. Overall, students were generally satisfied with the program, the internship requirements, and the effect of the program on their first job. Additionally, many graduates credited the Nonprofit Leadership Alliance with introducing them to the nonprofit sector and career opportunities within this sector (Altman et al., 2012). More specifically, researchers have also evaluated the benefits of the service-learning component of the Nonprofit Leadership Alliance certification. Students in a service-learning course related to Nonprofit Leadership Alliance certification believed that service learning is an important component that offers many rewards and that it reinforces understanding of course lessons (Gillman \& Ceglian, 2012, p. 87).

One crucial point of discussion in the field of undergraduate NPS programs focuses on the best methods to attract students to these programs. Many graduates of the Nonprofit Leadership Alliance certification program (the Certified Nonprofit Professional) reported that the program introduced them to careers in the nonprofit sector. These findings demonstrate the important role the Certified Nonprofit Professional credential plays in undergraduate NPS education by attracting students to the nonprofit sector. Additionally, these findings also demonstrate that students are largely unaware of careers in the nonprofit sector before entering college (Altman et al., 2012, p. 135). The Nonprofit Leadership Alliance is in the process of revising its credentialing program and bringing it to scale by offering pathways to complete the certificate to professionals and students from campuses not affiliated with the Nonprofit Leadership Alliance (R. Ashcraft, personal communication, August 13, 2019). As a result, one of the major unanswered questions regarding undergraduate NPS education is how to inform potential students about careers in the nonprofit field. A suggested method of solving this problem is strengthening career awareness at the high school level. Proponents of this method argue that it would increase students' awareness of and interest in the nonprofit sector, therefore increasing the number of students likely to enroll in undergraduate NPS programs (Schmidt, 2014, p. 9). Regardless of whether this method will serve as a solution, NPS programs throughout the country will continue to deal with this problem and must come up with innovative ways to attract and retain students to their programs. We address this further in the discussion of individual programs.

Finally, scholars have debated the best institutional location for NPS programs within universities, referred to as the "best place debate" (Mirabella \& Wish, 2000), with a variety of opinions emerging. Not surprisingly, this debate often exposes a bias 
among scholars to house these programs within their own discipline (Mirabella, 2015, p. 5) including schools of business, public administration, and social work. There have also been persuasive arguments for an interdisciplinary approach, particularly at the undergraduate level. We return to this discussion later in the article.

\section{Overview of Undergraduate Nonprofit Education}

In 2018, 144 universities were offering courses or programs in NPS in the United States, ${ }^{1}$ with universities offering a variety of program types (Figure 1). The number of universities offering programs is down slightly from the last census in 2015, which found 153 universities with this curriculum. About $70 \%$ of the universities offer three or more courses in NPS, while about $60 \%$ have a stated concentration in NPS. Slightly more than one third offer a certificate in NPS.

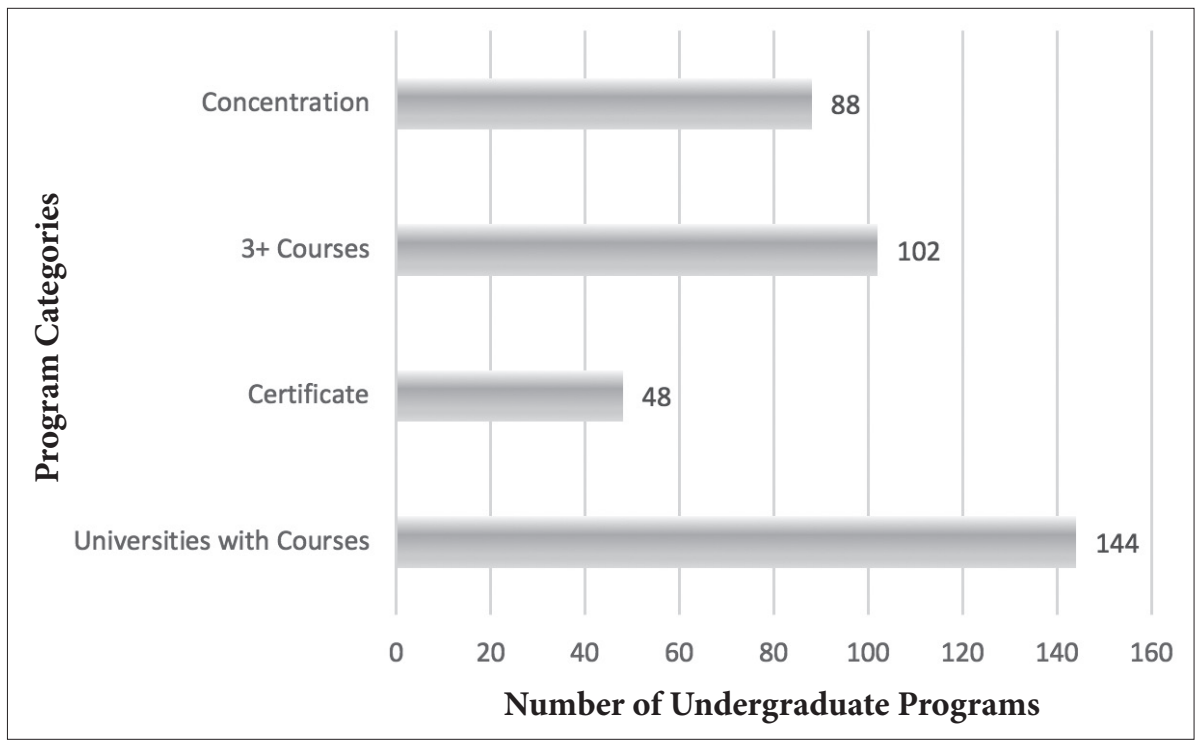

Figure 1. Undergraduate programs in nonprofit and philanthropic studies in 2018.

As found in previous studies (Dolch et. al., 2007), the Midwest continues to house the largest percentage of NPS programs (35\%; Figure 2). The percentage of programs in the South has remained relatively stable at $29 \%$. In contrast, in 2007, the percentage of NPS programs in the Northeast plummeted to $9 \%$, but in the past decade the percentage of programs in the Northeast grew to $19 \%$ of the total, while the percentage of programs in the West shrunk from $26 \%$ in 2007 to $17 \%$ today.

These universities offer over 800 NPS undergraduate courses, displayed by category in Figure 3. Today's census continues to show that a course in internal management skills makes up the largest plurality of course offerings, $46 \%$. Acquiring and managing resources (Financial Management and Fundraising) account for 20\% of all courses. An additional $15 \%$ of courses offered in an undergraduate setting focus more broadly

${ }^{1}$ The figures in this section are based on data from Seton Hall University's census of NPS programs in the United States (http://academic.shu.edu/npo/). 


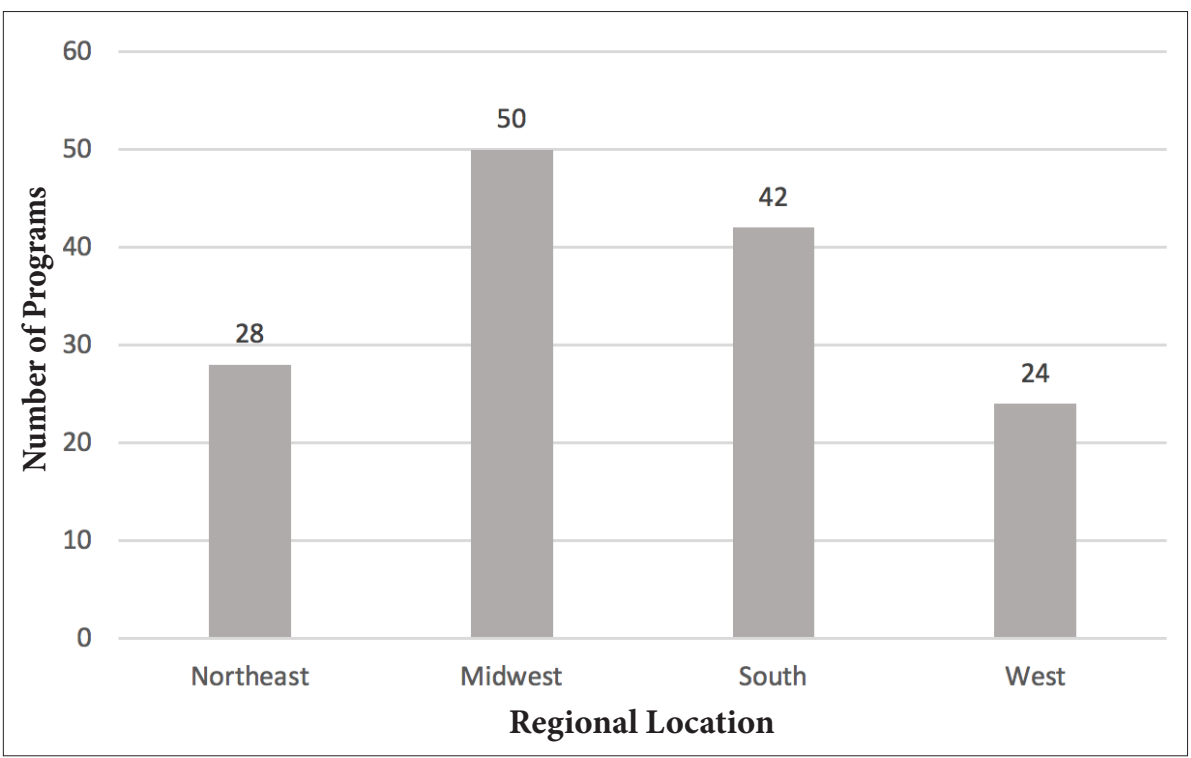

Figure 2. Undergraduate programs in nonprofit and philanthropic studies by regional location in 2018.

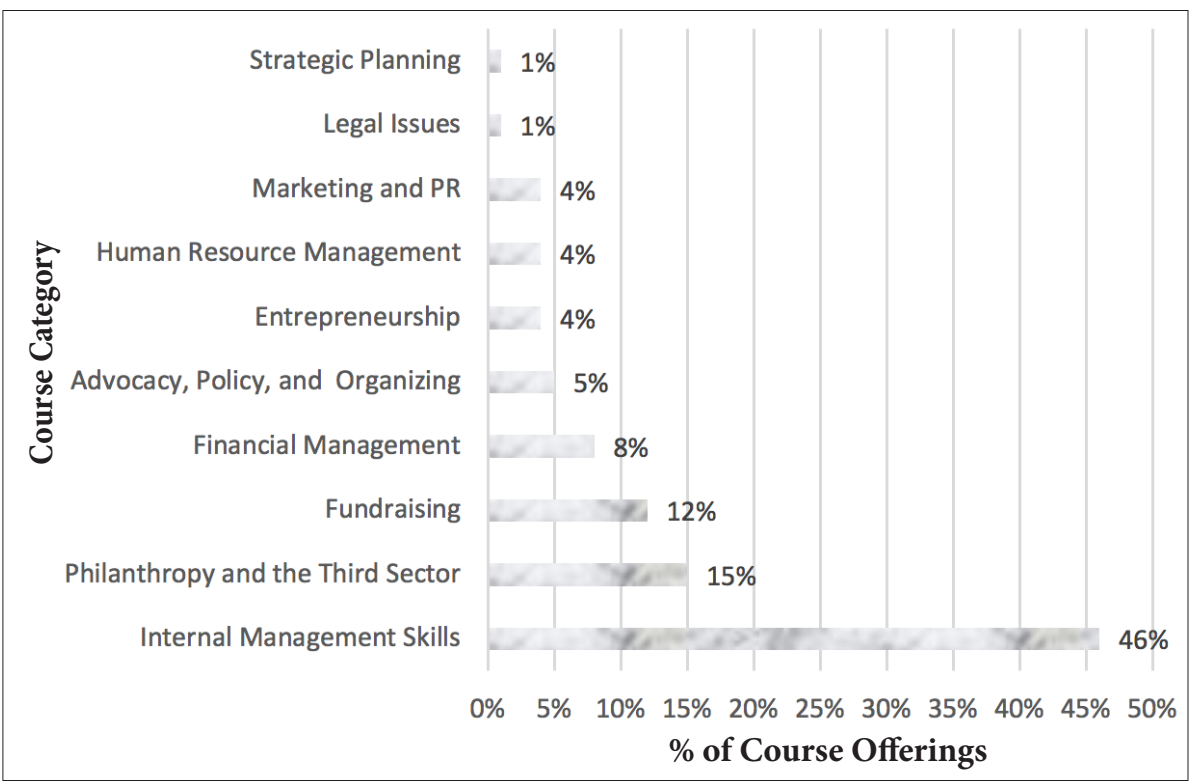

Figure 3. Undergraduate courses in nonprofit and philanthropic studies by course category in 2018. 
on philanthropy and the third sector. Next, advocacy, public policy, and community organizing make up about $5 \%$ of all courses offered. Finally, about $4 \%$ of the 800 -plus courses fall into the categories of marketing and PR, human resource management, and entrepreneurship.

Undergraduate programs in NPS are located in a variety of institutional schools and colleges (Figure 4). Most programs are housed in a school or college of continuing education (28\%), with an additional $20 \%$ offered through business schools. Programs are also located in schools of social work (12\%), colleges of arts and sciences (12\%), and schools of public administration (11\%). Finally, there are a variety of other schools or colleges, such as colleges of education, that make up the remaining $17 \%$ of the locations for these undergraduate programs, including a specialized school of philanthropy, which is a new development for the field. The location of undergraduate programs within the university contrasts sharply with the institutional location of graduate programs in NPS, where only a few programs are offered through schools of continuing education and most programs are offered in a college of arts and sciences or a school of public administration (Mirabella et al., 2019, p. 67). This could affect the development of feeder programs at the master's level, as more feeder programs usually develop as joint degrees between a department that houses graduate and undergraduate programs in NPS. Given that most of these programs are located within continuing education programs, there might be fewer opportunities for the development of undergraduate degrees.

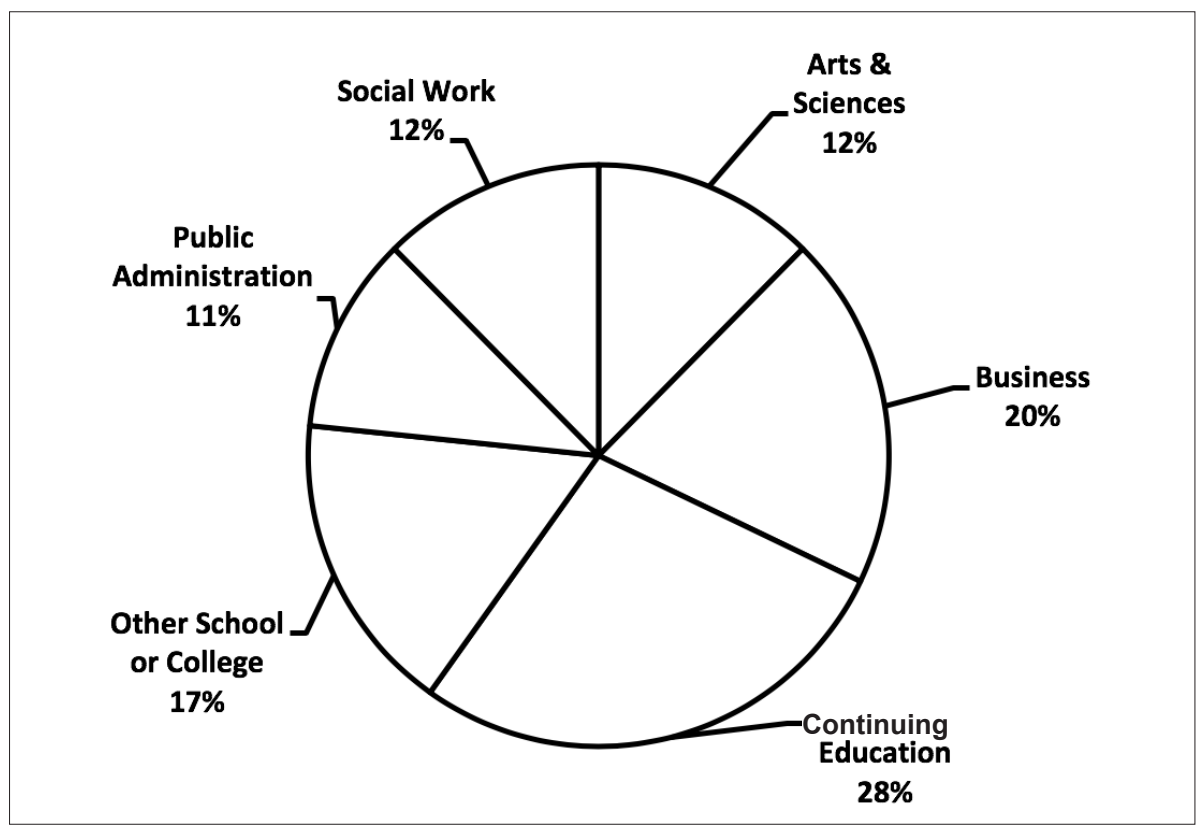

Figure 4. Institutional location of nonprofit and philanthropic studies undergraduate programs. 


\section{Four Programs Providing Insight on Program Uniqueness}

The study of NPS programs has traditionally relied on case studies. This essay also uses the case study approach to document NPS programs and their historical development and showcase differences between programs (Table 1). The selected cases identify programs' strengths and examine their responses to challenges. The four programs selected are housed at Grand Valley State University (GVSU), Indiana University Purdue University Indianapolis (IUPUI), Murray State University (MSU), and the University of Wisconsin-Whitewater (UWW).

As Vaughan and Sjoberg (1989) argued, cases may provide a valuable discourse on key issues. In this instance, the discourse is on key issues revealed by the strengths and weaknesses of these programs. All four programs analyzed in this study are based at public institutions. As such, all four institutions receive public funding, which, however, has dramatically declined over the past decade. At the same time, the four programs have been selected because they vary on a range of critical factors.

\section{Geographical Location}

The four programs are based in large, metropolitan areas (IUPUI and GVSU) and rural contexts (MSU and UWW). This diversity in geographical location has both an internal and external influence on the development of educational programs, as it shapes student population and-indirectly-influences curriculum. For instance, a nonprofit sector characterized by small organizations (in terms of financial and human resources) in Western Kentucky influences curriculum development and internship structures at MSU in a way that clearly differs from the experience at IUPUI and GVSU with large and professionalized nonprofit organizations and philanthropic institutions. The UWW experience falls somewhere in between, as it has proximity to small, local organizations and larger professionalized organizations in the surrounding cities.

\section{Institutional Location}

These programs also differ significantly in terms of institutional location. The effect and relevance of these differences on course delivery and content have been explored (Mirabella \& Wish, 2000). Programs based at GVSU, UWW, and MSU are housed in the College of Community and Public Service, College of Business and Economics, and College of Education and Human Services, respectively. The case of IUPUI significantly differs, as the bachelor of arts in philanthropic studies is housed in the country's first school of philanthropy, the Lilly Family School of Philanthropy, a setting that guarantees a different level of resources and support.

\section{Age of Program}

The nonprofit programs vary notably in terms of age. The nonprofit program at MSU is one of the oldest in the country with the establishment of a minor in the mid-1980s to which was added a major in 2011. The major in philanthropic studies at IUPUI was added to the graduate programs in 2010. The program at UWW is the newest, as an emphasis was created in 2018 and a minor added in nonprofit management in 2019. In 1971, GVSU began offering degrees in public administration, with courses in nonprofit management offered as electives. Over the ensuing four decades, emphases and coursework in nonprofit management, nonprofit budgeting and finance, and community health were added continually, and the undergraduate program formally changed its name to Public and Nonprofit Administration in 2013. 


\section{Size of University (by Undergraduate Student Population)}

The size of the university-measured in total undergraduate enrollment-differs significantly, ranging from 28,710 (IUPUI) and 21,680 (GVSU) to 11,722 (UWW) and 8,117 (MSU). At a program level, the size of the programs varies from 10 students in the emphasis at UWW, to 60 major and 30 minor students at MSU, to 50 major and 20 minor students at IUPUI, and 190 majors and 60 minor students at GVSU, with approximately 80 students annually enrolling in the nonprofit emphasis of the Public \& Nonprofit Administration major and another 50 choosing the nonprofit minor.

\section{Resources (Financial and Faculty)}

While most of the programs in this study are comparable in terms of faculty resources ( 3 to 5 tenured/tenure track), the Lilly Family School of Philanthropy stands out with 21 faculty members. Also, in terms of financial resources, the Lilly Family School of Philanthropy is distinctive with a substantial amount of its budget coming from contracts, grants, and other earned income with tuition contributing a growing but smaller proportion. The other institutions share a familiar characteristic of today's higher education landscape with state appropriations declining to between $10 \%$ and $30 \%$ of the budget.

\section{Key Characteristics}

As a field still in development, NPS has not yet assumed a homogenized character like many other disciplines. Therefore, there is a notable programmatic freedom with programs developing areas of strength and innovation. The Nonprofit Leadership Studies program at MSU has developed a strong identity around service learning and student philanthropy, as most courses include a service-learning component and the program has developed strong partnerships with the local nonprofit community. Partially influenced by a long-time affiliation with American Humanics/Nonprofit Leadership Alliance and grants from the W.K. Kellogg Foundation, the program developed a service-learning scholar designation, which recognizes students for the completion of service-learning projects at the time of graduation. Additionally, the establishment of the Giving Back Endowment allowed for the implementation of a student philanthropy initiative.

In the case of IUPUI, from its inception, the curriculum was designed to include seven of the 11 high-impact practices (HIPs) in undergraduate education, including learning communities, writing-intensive courses, collaborative assignments, undergraduate research, service-learning, internships, and capstone courses (Kuh, 2008). Over time, the program incorporated two additional HIPs, electronic portfolios, and first-year seminars to enhance student commitment and success in the major. These pedagogical and curricular features are strengths in promoting student retention and deep learning (Watson, Kuh, Rhodes, Light, \& Chen, 2016). Further, the program's embedded use of HIPs builds upon IUPUI's national reputation for service learning and civic engagement and its long history of employing such pedagogies.

The rapid growth of the UWW program benefited from administrative support and the affiliation with the Helen Bader Institute for Nonprofit Management at the University of Wisconsin-Milwaukee. Its educational programming, research, and relations with nonprofit organizations provide an unparalleled collaboration resource 
to the UWW Nonprofit Management Studies Program and its strong, practice-oriented faculty.

The program at GVSU emphasizes a practice orientation thanks to the partnership with the Dorothy A. Johnson Center for Philanthropy and a focused recruitment of faculty with 10 years of professional experience. Hallmarks of the program include the small size of classes and student involvement in faculty research.

\section{Table 1}

Program Institutional Profiles: Grand Valley State University, Murray State University, Indiana University Purdue University Indianapolis, and University of WisconsinWhitewater

\begin{tabular}{cl}
\hline $\begin{array}{l}\text { Profile by } \\
\text { institution }\end{array}$ & Description \\
\hline Enrollment & \\
GVSU & 21,680 \\
IUPUI & 28,710 \\
MSU & 8,117 \\
UWW & 11,722 \\
\hline
\end{tabular}

Nonprofit and Philanthropic Studies Program

GVSU $\quad 80$ majors and 50 minors

IUPUI 50 majors and 20 minors

MSU $\quad 60$ majors and 30 minors

UWW $\quad 10$ students

Degrees and Certificates Awarded

GCSU Bachelor of public and nonprofit administration, master of philanthropy and nonprofit leadership, and a graduate certificate in nonprofit leadership

IUPUI BA major and minor (traditional and honors) in philanthropic studies, proposed undergraduate and graduate certificates in philanthropic fundraising, graduate certificate and MA in philanthropic studies, $\mathrm{PhD}$ in philanthropic studies

MSU BA and BS in leadership studies, graduate certificate in nonprofit leadership studies

UWW Bachelor of business administration - nonprofit emphasis, and nonprofit management studies minor

Public Allocation Ratio

GVSU $\quad 20.5 \%$ state appropriations, $79.5 \%$ tuition

IUPUI $\quad 15 \%$ state appropriations, $27 \%$ tuition, $22 \%$ grants

MSU $\quad 30 \%$ state appropriations, $70 \%$ tuition

UWW $\quad 10.6 \%$ state appropriations 


\section{Table 1 (cont.)}

\section{Profile by institution Description}

$\begin{array}{ll}\text { Faculty Dedicated to Program } \\ \text { GSVU } & 4 \\ \text { IUPUI } & 21 \\ \text { MSU } & 3 \text { tenured/tenure track and 2 lecturers } \\ \text { UWW } & 3 \text { tenure track and 1 lecturer (part-time) }\end{array}$

Geographical Location

$\begin{array}{ll}\text { GVSU } & \text { Urban } \\ \text { IUPUI } & \text { Urban } \\ \text { MSU } & \text { Rural } \\ \text { UWW } & \text { Rural }\end{array}$

Institutional Location

GVSU College of Community and Public Service

IUPUI Lilly Family School of Philanthropy

MSU College of Education and Human Services

UWW College of Business and Economics

Organizational Chart

GVSU The College of Community and Public Service has four schools: School of Social Work; School of Criminal Justice; School of Hospitality and Tourism Management; and the School of Public, Nonprofit, and Health Administration.

IUPUI The Lilly Family School of Philanthropy is a stand-alone academic unit that operates several institutes including The Fund Raising School, the Women's Philanthropy Institute, the Lake Institute on Faith and Giving, the Mays Family Institute on Diverse Philanthropy, and the Muslim Philanthropy Institute.

MSU The College of Education and Human Services has four departments; the Department of Community Leadership and Human Services includes the programs of Criminal Justice, Social Work, and Nonprofit Leadership Studies.

UWW The College of Business and Economics has seven departments; the Department of Management supports a nonprofit management studies emphasis and an interdisciplinary undergraduate minor. 


\section{Program Challenges}

The characteristics of these four programs allow us to identify a series of challenges that academic managers face when developing undergraduate programs in NPS. Some of these challenges are common to all programs and appear to be specific to either the field of NPS or broader trends in higher education. Declining state funds to public institutions and the lack of knowledge among prospective students about a relatively new field of study are examples of this first set of challenges. By contrast, other challenges depend on the characteristics and contexts of the individual programs. Geographical location and relationship to other campuses in large university systems are instances of challenges rooted in individual characteristics. Table 2 provides an overview of these challenges and here we discuss them in further detail.

\section{Effects of Trends in Higher Education: Resources (Financial and Human)}

All four institutions are public universities and as such have all faced a decline in state funds to higher education. Declining state appropriations is a higher education trend common to most institutions, which raises concerns about resources and financial sustainability. The Center on Budget and Policy Priorities reported that state funding for public colleges in 2018 declined by more than $\$ 7$ billion from 2008 (M. Mitchell, Leachman, Masterson, \& Waxman, 2018). The decline in spending per student in the 2008-2018 period varied depending on state, with declines of $27.2 \%$ in Kentucky (MSU), 22.8\% in Wisconsin (UWW), 16.7\% in Michigan (GVSU), and 1.2\% in Indiana (IUPUI; M. Mitchell et al., 2018, p. 4).

Because of financial constraints, universities nationwide have sought additional sources of income, often by raising tuition and privileging out-of-state students (Han, Jaquette, \& Salazar, n.d.; M. Mitchell et al., 2018). Additionally, multiple states have introduced performance-based funding matrices, a mechanism by which public institutions compete for at least a portion of state funding. MSU and the Nonprofit Leadership Studies program exemplify the effect of state-level educational policies on academic programming. In fact, Kentucky is only one out of five states that decreased public allocations to higher education in the 2018-2019 fiscal year, compared with 2017-2018 (Grapevine Project, n.d.). Furthermore, MSU was one of the Kentucky institutions of higher education excluded from the $\$ 31$ million pool allocated based on performance matrices (Ockerman, 2018), which thus increased pressure on student recruitment and moved retention concerns to the forefront.

\section{The Reality of a New Field of Study}

Given the origins of the field of NPS at the graduate level during the 1980s and 1990 s, only recently have institutions invested resources in the creation of undergraduate programs. The recruitment of undergraduate students presents, however, challenges, as prospective students have no clear career trajectories in mind when selecting an academic major during their junior or senior year in high school. The many misconceptions surrounding the nonprofit sector and the general lack of knowledge among the broader public about career options in the sector represent major recruitment obstacles. Major factors include parental skepticism and lack of knowledge about the field among high school counselors. The common misconception about the nonprofit sector leads to parental concerns regarding gainful employment options and starting salaries in the nonprofit sector. Likewise, the inexperience of counselors in 


\section{Table 2}

Program Challenges

\begin{tabular}{|c|c|c|c|c|}
\hline Challenge & GVSU & MSU & IUPUI & UWW \\
\hline Resources & $\begin{array}{l}\text { Public administration and } \\
\text { policy faculty rather than } \\
\text { nonprofit sector }\end{array}$ & $\begin{array}{l}\text { Public funds have steadily } \\
\text { declined over the past years }\end{array}$ & $\begin{array}{l}\text { Generates other sources of } \\
\text { earned income to subsidize } \\
\text { undergraduate education }\end{array}$ & $\begin{array}{l}\text { Able to procure resources } \\
\text { as requested }\end{array}$ \\
\hline $\begin{array}{l}\text { Nonprofit } \\
\text { Program } \\
\text { Promotion }\end{array}$ & $\begin{array}{l}\text { Discovery program, } \\
\text { competition with other } \\
\text { programs for students }\end{array}$ & $\begin{array}{l}\text { Discovery program, } \\
\text { competition with } \\
\text { established majors, lack of } \\
\text { resources earmarked for } \\
\text { recruitment/promotion } \\
\text { purposes }\end{array}$ & $\begin{array}{l}\text { Centralized campus } \\
\text { recruitment rather than } \\
\text { at school level, discovery } \\
\text { program, competition with } \\
\text { well-established majors }\end{array}$ & $\begin{array}{l}\text { Discovery program, } \\
\text { competition with other } \\
\text { programs for students }\end{array}$ \\
\hline $\begin{array}{l}\text { Student } \\
\text { Awareness of } \\
\text { NPO Sector } \\
\text { and Career } \\
\text { Opportunities }\end{array}$ & $\begin{array}{l}\text { Student awareness } \\
\text { increasing, but lower than } \\
\text { preferred }\end{array}$ & $\begin{array}{l}\text { Limited knowledge among } \\
\text { students; prospective } \\
\text { students not aware of } \\
\text { program and career } \\
\text { opportunities }\end{array}$ & $\begin{array}{l}\text { Students not aware of } \\
\text { program and of career and } \\
\text { postgraduate opportunities }\end{array}$ & $\begin{array}{l}\text { Limited student knowledge } \\
\text { of NPO sector and career } \\
\text { opportunities }\end{array}$ \\
\hline Location & $\begin{array}{l}\text { Downtown campus rather } \\
\text { than main campus }\end{array}$ & Rural: declining population & Urban campus of IU system & Rural campus \\
\hline
\end{tabular}

Note. GVSU = Grand Valley State University; MSU = Murray State University; IUPUI = Indiana University Purdue University Indianapolis; UWW = University of Wisconsin-Whitewater. 
this area represents a significant barrier, as students, and their families, simply are not aware of these degrees and the significant career and postgraduate opportunities.

\section{Discovery Programs and University-Specific Recruitment Efforts}

This lack of awareness results in a process by which students declare a major in NPS at GVSU, MSU, and IUPUI. These programs are "discovery programs." That is, compared to students in other academic majors, a significantly higher percentage of students in undergraduate nonprofit programs transfer into this major from a different one. Most students do not enroll at GVSU, MSU, and IUPUI with the intention of obtaining a bachelor's degree in NPS, but rather they "discover" these programs once on campus while pursuing a different major. This creates a challenging and competitive environment, as programs must develop strategies that attract students and design curricula that facilitate (internal) transfer students and, in doing so, they risk competing over students with other programs within the same university system. UWW has already experienced this challenge to some degree with enrollment in its Nonprofit Management Studies Program. Recruitment for discovery programs is further complicated by the recruitment system at each university. At IUPUI, the Lilly Family School of Philanthropy experiences the challenges of centralized undergraduate recruitment and admissions. Academic units are encouraged to coordinate efforts with the central office rather than conduct independent initiatives. In other cases, like MSU and GVSU, where recruitment is decentralized to the college/school level, recruiters are not necessarily familiar with the field of NPS when these programs are located in large colleges with a strong disciplinary focus other than NPS.

\section{Location (Geographical and Campus)}

Location, both geographical and in terms of proximity to main campus, plays a central role in the recruitment of students. The Nonprofit Studies Program is located on the downtown Grand Rapids campus of GVSU, approximately 10 miles from the main campus in rural Allendale. Most undergraduate students reside on the main campus and take most of their classes there, rarely making their way to the downtown location unless for a specific reason. This lack of proximity to most undergraduate students creates challenges in terms of attracting students into the program. Proximity is the key term. In the case of MSU, family tradition has played a crucial role in recruitment. MSU is the college of choice for many students who follow in the footsteps of family members. Traditionally, students have come from small towns in rural Western Kentucky. MSU's footprint, roughly overlapping Western Kentucky, extends over counties that have experienced flat or declining population growth. ${ }^{2}$

\section{Program Strategies to Overcome Challenges}

The four universities profiled have utilized several strategies to overcome the challenges identified (Table 3). Although each institution has different goals and resources to bring to the project of strengthening its programs, many of the identified strategies have been utilized at multiple institutions. These strategies may be applicable to other institutions that are seeking to overcome similar challenges. These strategies have been developed either to leverage and capitalize on programs' strengths or to address and overcome challenges. 
One of the major challenges common to all four programs is that they are discovery programs, which is a result of the novelty of the field. This is a significant challenge for programs, as sustainability is a key issue in times of budgetary constraint. The experience of the programs at the center of this study highlights a three-pronged strategy.

First, programs focused on increasing the possibility of discovery within the university by including introductory courses into the university general education sequence (as in the case of IUPUI, GVSU, and MSU) and the honors sequence (MSU), as well as by organizing campus-wide events aiming to connect students to the local nonprofit community (Nonprofit Connection Event at MSU, The Nonprofit Expo at IUPUI, and Nonprofit Week at UWW). All four institutions regularly host campus-wide information sessions to attract students who have not yet determined their program of study, while MSU has proactively worked to streamline curriculum to ensure that students can easily transfer into the program from other parts of the university. Two programs, GVSU and IUPUI, recently began offering students the opportunity to enter an accelerated degree program, which allows students to complete an undergraduate and a graduate degree in 5 years. UWW's nonprofit management studies minor aims to expose students from multiple disciplines to nonprofit studies by offering an interdisciplinary program that includes courses from humanities and social sciences alongside business education.

Second, programs focused on developing articulation agreements with local community colleges to provide students with clear pathways into their academic majors (MSU, IUPUI, and GVSU). IUPUI has developed articulation agreements with the state community college system to make student transfer easier, while MSU has developed $2+2$ agreements with local community colleges to create pathways for students who wish to transfer to the university. GVSU has also developed relationships with numerous "feeder" community colleges.

Last, programs have developed long-term strategies to familiarize high school students and their parents with the possibilities of careers in the nonprofit sector by offering dual-credit courses (MSU) or hosting high school counselors (IUPUI). IUPUI proactively hosts events for high school guidance counselors to inform them about the potential for students to major in philanthropic studies as an undergraduate, while MSU has begun offering dual-credit courses that allow high school students to receive high school and college credit for enrolling in a nonprofit management undergraduate course.

Likewise, all four institutions have identified the need to strengthen and maintain good relationships with nonprofit professionals and programs in their communities. Engagement with their communities takes many forms. Of note, GVSU has established a student-led chapter of the Association of Fundraising Professionals (AFP) on campus to engage nonprofit professionals in the program, while UWW hosts an annual Nonprofit Week of events showcasing nonprofit research and nonprofits in the arts and invites nonprofit practitioners to share their employment experiences with students. Local nonprofit organizations also participate in the twice-yearly campus-wide career fairs. IUPUI hosts a student organization for the major, regularly presents local and national philanthropic leaders as campus speakers, and engages alumni in career services programming for students. MSU hosts practice-oriented workshops and trainings to connect the Nonprofit Leadership Program with nonprofit professionals in the community. 


\begin{tabular}{|c|c|c|c|c|}
\hline Strategy & GVSU & MSU & IUPUI & UWW \\
\hline $\begin{array}{l}\text { Nonprofit } \\
\text { Course Offerings } \\
\text { and Program } \\
\text { Accessibility }\end{array}$ & $\begin{array}{l}\text { Available general } \\
\text { education courses to } \\
\text { 1st/2nd-year students; } \\
\text { accelerated program; } \\
\text { more online and hybrid } \\
\text { courses; Spring/Summer } \\
\text { courses so students } \\
\text { can complete while on } \\
\text { internship }\end{array}$ & $\begin{array}{l}\text { Streamlined NPS } \\
\text { curriculum to facilitate } \\
\text { internal transfers; } \\
\text { service learning as } \\
\text { a strategy to retain } \\
\text { students }\end{array}$ & $\begin{array}{l}\text { Accelerated program to attract } \\
\text { highly motivated students from } \\
\text { in and out of state; honors major } \\
\text { and minor available; minor in } \\
\text { philanthropic studies; proposed } \\
\text { certificate in philanthropic } \\
\text { fundraising; available general } \\
\text { education courses to students } \\
\text { across campus; full-time recruiter } \\
\text { responsible for promoting grad } \\
\text { programs and building relations with } \\
\text { undergrad recruitment/admissions }\end{array}$ & $\begin{array}{l}\text { Intro nonprofit studies } \\
\text { course available to all } \\
\text { Bachelor of Business } \\
\text { Administration } \\
\text { (BBA) students; } \\
\text { interdisciplinary } \\
\text { nonprofit studies minor } \\
\text { program available to } \\
\text { both BBA and non-BBA } \\
\text { students; internships as } \\
\text { form of service learning }\end{array}$ \\
\hline $\begin{array}{l}\text { External } \\
\text { Outreach: } \\
\text { a) NPO Sector } \\
\text { b) Other Schools }\end{array}$ & $\begin{array}{l}\text { Alumni Council whose } \\
\text { nonprofit members serve } \\
\text { as mentors and career } \\
\text { advisors; student-led } \\
\text { chapter of Association } \\
\text { of Fundraising } \\
\text { Professionals on campus }\end{array}$ & $\begin{array}{l}\text { Partnerships with local } \\
\text { high schools (primarily } \\
\text { through dual-credit } \\
\text { courses and campus } \\
\text { events); links with } \\
\text { community colleges to } \\
\text { facilitate credit transfer; } \\
\text { practice-oriented } \\
\text { workshops and } \\
\text { trainings targeting } \\
\text { adult learners from the } \\
\text { nonprofit sector }\end{array}$ & $\begin{array}{l}\text { Information outreach to local } \\
\text { high school guidance counselors; } \\
\text { participation in campus recruitment } \\
\text { and orientation events; student } \\
\text { organization in the major; alumni } \\
\text { participate in networking and } \\
\text { career services programming; local } \\
\text { and national philanthropic leaders } \\
\text { hosted as speakers on campus; } \\
\text { relationships with local and national } \\
\text { youth leadership/service programs } \\
\text { and conferences }\end{array}$ & $\begin{array}{l}\text { Dedicated week of } \\
\text { nonprofit informational } \\
\text { events on campus with } \\
\text { guest speakers from } \\
\text { nonprofit organizations; } \\
\text { program advisory } \\
\text { committee with } \\
\text { members from local } \\
\text { nonprofit organizations }\end{array}$ \\
\hline
\end{tabular}

Note. GVSU = Grand Valley State University; MSU = Murray State University; IUPUI = Indiana University Purdue University Indianapolis; UWW = University of Wisconsin-Whitewater. 
Finally, each program has leveraged its strengths. For example, the use of HIPs as a means of engaging students and the community is a key facet of all four institutions' undergraduate NPS programs. IUPUI participates in national and international associations affiliated with HIPs and partners extensively with communities of practices organized around HIPs. The campus has a national reputation in civic engagement and its philanthropic studies curriculum is grounded in service learning, civic engagement, and e-portfolios (i.e., digital collections of student learning created and reflected upon by students to demonstrate their achievement and growth); includes a Learning by Giving course through which students grant $\$ 10,000$, provided by a donor, to local nonprofits; and requires for-credit internships and a senior capstone experience. Both MSU and UWW have made service learning one of the cornerstones of their programs, in addition to viewing it as a deliberate strategy to retain students and to attract media attention for the program.

MSU has emphasized service learning and student philanthropy. The Nonprofit Leadership Studies program was instrumental in introducing the service-learning methodology to MSU. Between 1998 and 2009, the Nonprofit Leadership Studies program received three grants from the W.K. Kellogg Foundation for a total of $\$ 352,000$ to develop service-learning manuals and training workshops locally, nationally, and internationally, as well as to establish the Service-Learning Scholars Program and the MSU Center for Service Learning and Civic Engagement. The Nonprofit Leadership Studies program has also developed the Giving Back programs, which seek "to advance the understanding, appreciation, and application of the principles of altruism, generosity, caring, and service to others among Murray State University students and faculty and across the Murray/Calloway County community" (MSU, n.d., para. 1). Among these programs, the course Philanthropic Foundations and Grant-Making provides students the opportunity to go through a grant-making process that culminates with the awarding of the $\$ 3,000$ grant to a local nonprofit organization. GVSU annually offers undergraduate students the opportunity to participate in a year-long servicelearning project that culminates in a 1-week hands-on experience in the community.

\section{Discussion}

Despite the program diversity among these profiled institutions, all are engaged in actions to improve the public awareness of the NPS field as an important and beneficial academic major and career pathway to gainful and meaningful employment. These programs maintain affiliation with national organizations such as the Association for Research on Nonprofit Organizations and Voluntary Action (ARNOVA) and Nonprofit Academic Centers Council (NACC). They could foster collaboration with philanthropic/nonprofit programs across the country on national service-learning initiatives to provide increased program student and family awareness of NPS. At the least, they should continue to emphasize service learning and other HIPs in undergraduate education as integral aspects of their programs because of the pedagogical value and interest of the students.

These programs are attempting to establish bookends to the academic experience. All are concerned about the recruitment of students from high schools, community colleges, and their campuses. They are developing articulation agreements with community colleges and engaging in nonprofit fairs and service projects with high schools. 
In addition to the traditional 4-year college experience, they are developing 3-2 and 4-1 programs in which students can earn a master's degree in addition to their undergraduate degree. The realization is that recruitment into these programs needs attention because the collective experience is that very few philanthropic/nonprofit majors come to colleges and universities expecting to major in the area. Their awareness and interest must be actively cultivated, and their employability upon graduation must be enhanced through access to internships, cocurricular learning experiences, and established paths into graduate study.

In general, program viability is a concern on any campus. In large part, program viability depends on funding. As the budgetary shift on campuses has moved to increasing emphasis on self-generated funds, the programs discussed, like others across the country, have tried to programmatically distinguish themselves and, in the case of IUPUI and MSU, to develop alternative revenue streams from grants, philanthropy, and training fees. An apparent aspect of viability for each nonprofit program discussed is the strong support of college and university administration-and this should never be taken for granted.

We hope that this article reinforces the practices within some NPS programs and suggests practices that will ensure program viability and enhancement in others, resulting in growth for the field. Program administration and continued development are challenges to established and new programs. We can learn a lot from each other. At the least, we can recognize that other programs struggle with the same issues and concerns as our own.

\section{Recommendations}

We offer the following recommendations for increasing awareness of and recruitment to NPS programs to help program administrators navigate the operating environments for such programs, which, despite their complexity, offer numerous opportunities. These recommendations are organized into four categories: (1) academic, (2) resources, (3) on- and off-campus, and (4) marketing to the larger field.

Academic recommendations relate to the format and delivery of degree programs in ways that articulate and enhance career pathways for students. Providing general education courses can introduce NPS to the larger campus of students. When such courses also fulfill entry-level requirements for minors, certificates, or majors, they can facilitate selection of the field as a program of study. Online and hybrid options are becoming increasingly important in undergraduate higher education. Given that the programs in this study tend to serve regional bases of students, such options have the potential to open access to campus degree programs across a wider geography. However, this access must be tempered by the effect on NPS pedagogies and curricula, which tend to place a premium on local community engagement-a feature difficult to replicate online. Additionally, clearer NPS pathways can be established for students through articulation agreements with 2 -year institutions and through accelerated $4+1$ or $3+2$ options resulting in a bachelor's and master's degree within 5 years.

Resource recommendations involve reducing barriers to discovery and attracting NPS majors through the provision of financial support that encourages retention and completion. As the NPS field is dedicated to the study of philanthropy, broadly defined, programs should engage in fundraising to cultivate scholarships to attract incoming students and retain students already on campus. Scholarship options can range from 
full rides to partial and can be awarded based on need, on merit, or as encouragement for pursuing experiences such as internships, research, service, or study abroad. Research has indicated that even small scholarships of $\$ 1,000$ can increase the probability of student retention (Singell, 2003). Given that most students discover NPS majors after arriving on campus, the development of on-campus service leadership and scholarship programs that pay students small stipends and scholarships for participating in various forms of civic engagement, service leadership, and peer mentorship can facilitate connections with and attract these majors.

On- and off-campus strategy recommendations include ways to pursue or enhance recruitment activities depending upon campus contexts. For campuses with centralized recruitment operations, programs can provide ongoing cultivation and education for their assigned recruitment liaisons who represent them to off-campus constituencies. This process may involve regular (e.g., quarterly, semiannual, annual) training presentations that provide talking points, important facts about the NPS program, and materials for use in the field. Ensuring that campus tours for prospective students and their families show and/or discuss the NPS program is also of critical importance. Additionally, programs should identify the other programs on campus from which their majors and minors have come, and make sure that associated academic advisors in those programs and departments have necessary information to facilitate selection of NPS programs when students are interested in an academic major change. If institutions have general academic advisors for undecided majors, they should also be included in such efforts. Depending upon the available resources for decentralized recruiting operations, NPS may focus energies on populations such as guidance counselors at the largest feeder high schools in the region or students in philanthropy and service-related leadership organizations and programs such as Kiwanis Key Clubs or community foundation youth leadership programs. An array of communication, event, and other engagement strategies can be customized for each context. Last, NPS must engage their alumni, who are the best ambassadors for the success of these programs. Facilitating opportunities for alumni not only to interact with current students but also to their share their successes and career pathways through stories that can be disseminated through numerous media channels can help engage the unfortunate and inaccurate public perception that nonprofit and philanthropic careers are limited and require a vow of poverty.

Marketing in the field recommendations are perhaps the boldest of all suggested. Collectively, NPS programs have gradually made space for the formal academic study of philanthropy and nonprofit organizations in the academy despite the admonitions and objections of many. A process that took more than 40 years, it has led NPS to its status as a viable and important field of study with great potential and promise. An equally Herculean effort will be needed from NPS programs to create public awareness about NPS and change public perception-especially parent and prospective student perception-that NPS is not a "destination" major-meaning the first one chosen upon admission into an institution. NPS programs have an opportunity to partner with disciplinary associations such as the Nonprofit Academic Centers Council (NACC); the Association for Research on Nonprofit Organizations and Voluntary Action (ARNOVA); the Network of Schools of Public Policy, Affairs, and Administration (NASPAA); and others to collaborate on national public awareness campaigns to 
dispel myths about NPS careers and opportunities. Such efforts should also involve professional associations that engage practice and managerial leaders in the field such as the Young Nonprofit Professionals Network (YNPN), Association of Fundraising Professionals (AFP), and Emerging Practitioners in Philanthropy (EPIP). Collectively, these organizations can affect the public consciousness and conversation surrounding not only the viability of nonprofit careers but also their importance for the successful functioning of democratic societies. Additionally, NPS programs tend to also house or be connected to public service and continuing professional education programming that reaches external audiences regionally, nationally, and internationally. NPS programs should leverage these relationships to market their undergraduate options to the experienced professionals consuming these continuing education resources, who likely have college-aged young people in their lives and social circles. Since such professionals likely majored in other fields and may have "stumbled" upon the nonprofit sector as their career choice, it is important they receive information about the new direct pathways into the field afforded by NPS programs and have the necessary information to share with students in their families or social networks.

\section{Final Thoughts}

The interdisciplinary nature of NPS drives many of the program strengths and challenges presented in this article. NPS does not easily fit within preexisting university structures or in the public imagination about undergraduate majors. Consequently, NPS must be creative in developing its identity as a field and in engaging it constituencies to communicate its value. Burlingame (2009) and Young (1999) argued that the interdisciplinary character of NPS requires the incorporation of a strong liberal arts orientation, particularly at the undergraduate level. This approach encourages a sense of what life is, as well as what life can be, in a community. In a 2001 panel discussion (Hall et al., 2001), O'Neill, another founder of NPS, quite forcefully maintained that undergraduate education should never focus on management; rather he recommended that undergraduates major in philosophy, history, sociology, and other disciplines of the liberal arts. Leadership, not management, is a recognized outcome of a liberal education. Management is the proper focus of professional graduate education.

This dichotomy between management and leadership identified by the early NPS educators still confronts this area of study with programs often located in public administration or business schools. With the increased urgency for postgraduation employment, propelled in part by student debt and the tendency to see college as an apprenticeship for business (note the Trump administration's emphasis on occupational training), students and parents are reluctant to embrace the liberal arts. Yet NPS supports both the academy's and society's goals of producing well-rounded graduates fully prepared to engage their communities-including the economy-as citizens. Undergraduate NPS education should counter these arguments with the overwhelming evidence of the economic value of a liberal education (Chopp, Frost, \& Weiss, 2016; Humphreys \& Carnevale, 2010; McPherson, 1998).

While we offer some possible insight and recommendations, nothing we share is the equivalent of the silver bullet. At a minimum, we have unashamedly set forth issues, problems, and concerns common to our universities and programs. We offered some responses. Most important, we pledge continued dialogue among ourselves and invite others to share their thoughts and insights with us and all other NPS educators. 


\section{References}

Altman, S., Carpenter, H., Dietrick, L., Strom, S. A., \& VanHorn, T. (2012). Impact of the Nonprofit Leadership Alliance, an undergraduate competency-based nonprofit program, on alumni career paths. Journal of Nonprofit Education and Leadership, 2(3), 123-139.

Ashcraft, R. F. (2001). Where nonprofit management education meets the undergraduate experience: American Humanics after 50 years. Public Performance \& Management Review, 25(1), 42-56. https://doi.org/10.1080/15309576.2001.11643644

Benenson, J., \& Moldow, E. (2017). Paying it forward. Journal of Public Affairs Education, 23(3), 885-902. https://doi.org/10.1080/15236803.2017.12002294

Burlingame, D. F. (2009). Nonprofit and philanthropic studies education: The need to emphasize leadership and liberal arts. Journal of Public Affairs Education, 15(1), 59-67. https://doi.org/10.1080/15236803.2009.12001543

Campbell, D. A. (2014). Practicing philanthropy in American higher education. Journal of Public Affairs Education, 20(2), 217-231. https://doi.org/10.1080/1523 6803.2014.12001783

Chopp, R., Frost, S., \& Weiss, D. H. (Eds.). (2016). Remaking college: Innovation and the liberal arts. Baltimore, MD: Johns Hopkins University Press.

Dolch, N. (2018). Ideology in the evolution of nonprofit academic programs. Journal of Ideology, 39(1), 1-14.

Dolch, N. A., Ernst, M., McClusky, J. E., Mirabella, R. M., \& Sadow, J. (2007). The nature of undergraduate nonprofit education: Models of curriculum delivery. Nonprofit and Voluntary Sector Quarterly, 36(4 Suppl.), 28S-50S. https:// doi.org/10.1177/0899764007305058

Dolch, N., Kidwell, R., Sadow, J., \& Smith, J. (1998). Nonprofit undergraduate education: Delivery models for curricula within the American Humanics program. In M. O'Neill \& K. Fletcher (Eds.), Nonprofit management education: U.S. and world perspectives (pp. 81-94). Wesport, CT: Praeger.

Fletcher, K. (2005). The impact of receiving a master's degree in nonprofit management on graduates' professional lives. Nonprofit and Voluntary Sector Quarterly, 34(4), 433-447. https://doi.org/10.1177/0899764005279762

Gillman, S. A., \& Ceglian, C. M. P. (2012). Service learning in Nonprofit Leadership Alliance (NLA): It's not a minor point. Journal of Nonprofit Education and Leadership, 2(2), 82-96.

Grapevine Project. (n.d.). One-year (FY18-FY19), two-year (FY17-FY19), and fiveyear (FY14-FY19) percent changes in state fiscal support for higher education [Table]. Retrieved from https://education.illinoisstate.edu/grapevine/tables/

Hall, P. D., O'Neill, M., Vinokur-Kaplan, D., Young, D. R., \& Lane, F. S. (2001). Panel discussion: Where you stand depends on where you sit: The implications of organizational location for university-based programs in nonprofit management. Public Performance \& Management Review, 25(1), 74-87. https://doi.org/10.1080 /15309576.2001.11643646 
Han, C., Jaquette, O., \& Salazar, K. (n.d.). Recruiting the out-of-state university: Offcampus recruiting by public research universities. Chicago, IL: Joyce Foundation.

Hatcher, J., \& Studer, M. (2014). Service learning and philanthropy. Theory Into Practice, 54(1), 11-19.

Humphreys, D., \& Carnevale, A. (2010). The economic value of liberal education. Retrieved from American Colleges \& Universities website: http://www.aacu.org/ resources/liberaleducation/index.cfm

Kuh, G. (2008). High-impact educational practices: What they are, who has access to them, and why they matter. Washington, DC: American Association of Colleges \& Universities.

McDonald, D., Miller, W., \& McDougle, L. (2017). Connecting through giving. Journal of Nonprofit Education and Leadership, 7(2), 110-122.

McPherson, M. S. (1998). The economic value of a liberal arts education. About Campus, 3(4), 13-17.

Mirabella, R. (2007). University-based educational programs in nonprofit management and philanthropic studies: A 10-year review and projections of future trends. Nonprofit and Voluntary Sector Quarterly, 36(4), 11-27. https://doi. org/10.1177/0899764007305051

Mirabella, R. (2015). Nonprofit management education. In Encyclopedia of public administration and public policy (Vols. 1-5, 3rd ed., pp. 1-7). New York, NY: Routledge.

Mirabella, R., Hoffman, T., Teo, T., \& McDonald, M. (2019). The evolution of nonprofit management and philanthropic studies in the United States: Are we now a disciplinary field. Journal of Nonprofit Education and Leadership, 9(1), 63-84. https://doi.org/10.18666/jnel-2019-v9-i1-9598

Mirabella, R., \& Renz, D. (2001). Nonprofit management outreach programs. Public Performance \& Management Review, 25(1), 14-29. https://doi.org/10.1080/15309 576.2001.11643642

Mirabella, R., \& Wish, N. (1999). Educational impact of graduate nonprofit degree programs. Nonprofit Management \& Leadership, 9(3), 329-340. https://doi. org/10.1002/nml.9309

Mirabella, R. M., \& Wish, N. B. (2000). The "best place" debate: A comparison of graduate education programs for nonprofit managers. Public Administration Review, 60(3), 219-229. https://doi.org/10.1111/0033-3352.00082

Mitchell, M., Leachman, M., Masterson, K., \& Waxman, S. (2018). Unkept promises: State cuts to higher education threaten access and equity. Washington, DC: Center on Budget and Policy Priorities.

Mitchell, T. (2015). Using a critical service-learning approach to facilitate civic identity development. Theory Into Practice, 54(1), 20-28. https://doi.org/10.1080/0040584 1.2015.977657 
Murray State University. (n.d.). Giving Back endowment. Retrieved November 4, 2019, from https:/www.murraystate.edu/academics/CollegesDepartments/ CollegeOfEducationandHumanServices/Scholarships AndFunding/ GivingBackEndowment/index.aspx

Ockerman, S. (2018, July 11). MSU shut out of state performance funding. Morehead News. Retrieved from https://www.themoreheadnews.com/news/msu-shut-outof-state-performance-funding/article_9313277c-850a-11e8-92bc-bbf2c28617cd. html

Olberding, J. (2012). Does student philanthropy work? Innovative Higher Education, $37(2), 71-87$.

Olberding, J., \& Hacker, W. (2016). Does the "service" in service learning go beyond the academic session? Journal of Nonprofit Education and Leadership, 6(1), 25-46. https://doi.org/10.18666/jnel-2016-v6-i1-7201

Rinella, J. (2016). A way of proceeding: The progression of nonprofit management education at Rockhurst University. Journal of Nonprofit Education and Leadership, 6(1), 60-71.

Schmidt, S. T. (2014). Pathways and peril: The state of undergraduate nonprofit studies. Journal of Nonprofit Education and Leadership, 4(1), 4-11.

Singell, L. D. (2003). Come and stay a while: Does financial aid effect retention conditioned on enrollment at a large public university? Economics of Education Review, 23(5), 459-471. https://doi.org/10.1016/j.econedurev.2003.10.006

Stroup, K. M. (2006). Building tomorrow's nonprofit workforce. Community College Journal, 77(3), 40-43.

Vaughan, T. R., \& Sjoberg, G. (1984). The individual and bureaucracy: An alternative meadian interpretation. Journal of Applied Behavioral Science, 20(1), 57-69. https://doi.org/10.1177/002188638402000111

Watson, C. E., Kuh, G. D., Rhodes, T., Light, T. P., \& Chen, H. L. (2016). Editorial: ePortfolios - The eleventh high-impact practice. International Journal of ePortfolios, 6(2), 65-69.

Weber, P., \& Brunt, C. (2019). Continuing to build knowledge: Undergraduate nonprofit programs in institutions of higher learning. Journal of Public Affairs Education. Advance online publication. https://doi.org/10.1080/15236803.2019.1607804

Weber, P. C., \& Witkowski, G. R. (2016). Philanthropic disruptions. Journal of Public Affairs Education, 22(1), 91-106.

Young, D. R. (1999). Nonprofit management studies in the United States: Current developments and future prospects. Journal of Public Affairs Education, 5(1), $13-$ 23. https://doi.org/10.1080/15236803.1999.12022049 